\title{
Protein metabolism and nutritional state in man
}

By Vernon R. Young, Laboratory of Human Nutrition, Department of Nutrition and Food Science and Clinical Research Center, Massachusetts Institute of Technology, Cambridge, Massachusetts 02139 and DenNis M. BIER, Departments of Medicine and Pediatrics, Washington University School of Medicine, St. Louis, Missouri 631 ro

In a previous symposia organized by this Society, the effects of dietary factors and of nutritional state on protein and amino acid metabolism in mammalian species, including man, have been discussed from various standpoints (e.g. Munro, 1969; Waterlow \& Stephen, 1969; Hoffenberg, 1972; Millward \& Garlick, I972; James, 1972; Millward et al. 1976; Millward, 1979; Smith, 1980; Reeds \& Lobely, 1980). In consideration of this and with available additional recent reviews (Waterlow et al. 1978; Garlick, 1980; Waterlow \& Stephen, 1981) we will take this opportunity to review results of some of our recent studies. These have exploited use of stable isotope probes to uncover responses, in adult.humans, of whole body amino acid kinetics to various nutritional conditions, especially the levels of dietary protein, amino acid and energy intake.

By way of an introduction, it should be emphasized that the major pathways of amino acid metabolism involve protein synthesis and breakdown, the formation of various $\mathrm{N}$-containing compounds, such as nucleic acids, the dispensable amino acids and creatine, and finally, those associated with amino acid catabolism. These three major pathways may either change in parallel or in reciprocal ways (Munro, I969) depending upon the particular tissue involved, the dietary factor(s) or nutritional health status of the host or both. Thus, it is necessary to extend approaches in human studies beyond the measurement of body nitrogen balance (Young, Scrimshaw et al. 198I) if we are better to understand the ways by which whole body $\mathrm{N}$ and amino acid homoeostasis is achieved in healthy humans under various nutritional states and in disease. Hence, we have used the approach proposed and developed by Waterlow and his colleagues (e.g. Waterlow et al. 1978). The long-term objective of this research is to develop more appropriate diagnostic tests for determination of protein and amino acid nutritional status and to improve estimations of the protein and amino acid requirements in healthy humans and in those who suffer illness.

The metabolism of amino acids and of tissue and organ proteins responds to changes in both the internal and external environments. In reference to the latter, the availability and quality of the nutrient supply are important factors. These may bring about transient changes in protein and amino acid metabolism as a consequence of the intermittent intake of meals (e.g. Young et al. 1969; Hussein et al. 1971; Garlick et al. 1980). In addition, the metabolic responses may have a longer-term, adaptive significance if the diet provides either an excess or a deficient intake of one or more nutrients in relation to the host's physiological requirement. 
The studies that we will describe, briefly, have focused mainly on the shorter-term changes in human protein and amino acid metabolism to nutritional factors; that is, before clinically significant alterations in body protein content and in nutritional status have occurred.

We begin with an account of the responses of whole body amino acid metabolism to alterations in the level of protein or energy intake and then we describe changes in the metabolism of specific amino acids to alterations in $\mathrm{N}$ and amino acid intake. Finally, the relationships between amino acid and energy metabolism will be examined with particular reference to the impact of intravenous glucose administration on aspects of whole body amino acid kinetics.

\section{Level of protein and energy intake}

The supply of amino acids and the availability of high energy intermediates (ATP and GTP) required for various stages in the synthesis of polypeptides and possibly during their subsequent breakdown (Dean, 1980) affect the status of cellular protein and amino acid metabolism. It is not surprising, therefore, that body $\mathrm{N}$ metabolism is highly sensitive to altered dietary intakes of both protein and energy. Thus, $\mathrm{N}$ balance becomes progressively less positive and then more negative when protein intakes approach and fall below a requirement level, respectively. Furthermore, for a given intake of dietary protein, $\mathrm{N}$ balance is affected by the level and source of dietary energy (Table 1 ). These $\mathrm{N}$ balance responses to changes in protein and energy intake may complicate estimation of requirements for dietary protein and of indispensable amino acids when they are derived from N balance criteria (e.g. Garza et al. 1976, 1977, 1978). For this practical reason alone it is instructive to explore the whole body mechanisms that

Table 1. A selected survey of some recent studies on the responses of $N$ balance in adults to changes in energy intake

\begin{tabular}{|c|c|c|c|}
\hline Subjects & Dietary conditions & $\mathrm{N}$ balance response & Author \\
\hline Young men & $\begin{array}{l}\text { Protein intake varied } \\
0.28-0.76 \mathrm{~g} / \mathrm{kg} \text { per } \mathrm{d}\end{array}$ & $\sim 2 \mathrm{mg} \mathrm{N} / \mathrm{kcal}$ & Inoue et al. (1973) \\
\hline Six young men & $\begin{array}{l}\text { Protein intake } 5-7 \% \text { of } \\
\text { dietary energy, } 12 \mathrm{~d} \\
\text { periods, at low E and } \\
\text { excess E }\end{array}$ & $\begin{array}{l}1.74 \mathrm{mg} \mathrm{N} / \mathrm{kcal} \mathrm{at} \\
\text { low E; } 112 \mathrm{mg} \\
\mathrm{N} / \mathrm{kcal} \text { at high E }\end{array}$ & Calloway (1975) \\
\hline Four young men & $\begin{array}{l}\text { Protein intake } 0.6 \mathrm{~g} / \mathrm{kg} \text {, } \\
3-4 \text { week diet periods }\end{array}$ & $1 \cdot 74 \mathrm{mg} \mathrm{N} / \mathrm{kcal}$ & Garza et al. (1976) \\
\hline Four young men & $\begin{array}{l}\text { Protein intake } 0.6 \mathrm{~g} / \mathrm{kg} \\
\text { plus dispensable amino } \\
\text { acids ( } \equiv 0.23 \text { g protein } / \\
\mathrm{kg} \text { ) }\end{array}$ & $\sim 3 \mathrm{mg} \mathrm{N} / \mathrm{kcal}$ & Garza et al. (1978) \\
\hline Young men ( 46 total) & $\begin{array}{l}\text { Variable energy and } \\
\text { protein intake among } \\
\text { groups }\end{array}$ & $\sim 3 \mathrm{mg} \mathrm{N} / \mathrm{kcal}$ & Kishi et al. (1978) \\
\hline Depleted patients & $\begin{array}{l}\text { Intravenous glucose, } N \\
\text { intake } 173 \mathrm{mg} / \mathrm{kg}\end{array}$ & $\mathrm{I} \cdot 7 \mathrm{mg} \mathrm{N} / \mathrm{kcal}$ & Elwyn et al. (1979) \\
\hline
\end{tabular}


might account for changes in $\mathrm{N}$ balance and alterations in the efficiency of dietary $\mathrm{N}$ retention to these variable levels of protein and energy intake.

We, (Motil, Matthews et al. 198I) have carried out a study to examine changes in whole body leucine and lysine metabolism in young men to alterations in dietary protein intake, using a primed constant infusion protocol, involving $\left[\mathrm{I}^{13} \mathrm{C}\right] \mathrm{leucine}$ and $\left[\alpha-{ }^{15} \mathrm{~N}\right] \mathrm{y}$ ysine given simultaneously (e.g. Matthews et al. 1980). In this experiment, three protein intake levels were studied; $\mathrm{I} .5,0.6$ and $0.1 \mathrm{~g}$ egg protein $/ \mathrm{kg}$ per $\mathrm{d}$. The $0.6 \mathrm{~g}$ protein $/ \mathrm{kg}$ per $\mathrm{d}$ intake level was chosen to represent an average maintenance requirement level (Garza et al. 1976) and to serve as the reference protein intake against which changes in leucine and lysine metabolism to increases or decreases in protein intake could be evaluated. Whole body leucine and lysine fluxes showed a decline (Fig. 1) with reduced protein intake although the actual fluxes were lower for lysine than for leucine, especially at the higher protein intakes. Similar discrepancies in whole body leucine and lysine fluxes have been described in growing pigs (Simon, Munchmeyer et al. 1978). While the mechanisms underlying these differences are uncertain, they may be related, in part, to differences in the sizes of the free amino acid pools in the tissues and particularly the different responses of the free pools of lysine and leucine to changes in dietary intake of these amino acids (e.g. Pion, 1973).

A summary of the responses of the components of leucine flux (oxidation, outflow of leucine from the metabolic pool into proteins and inflow via protein

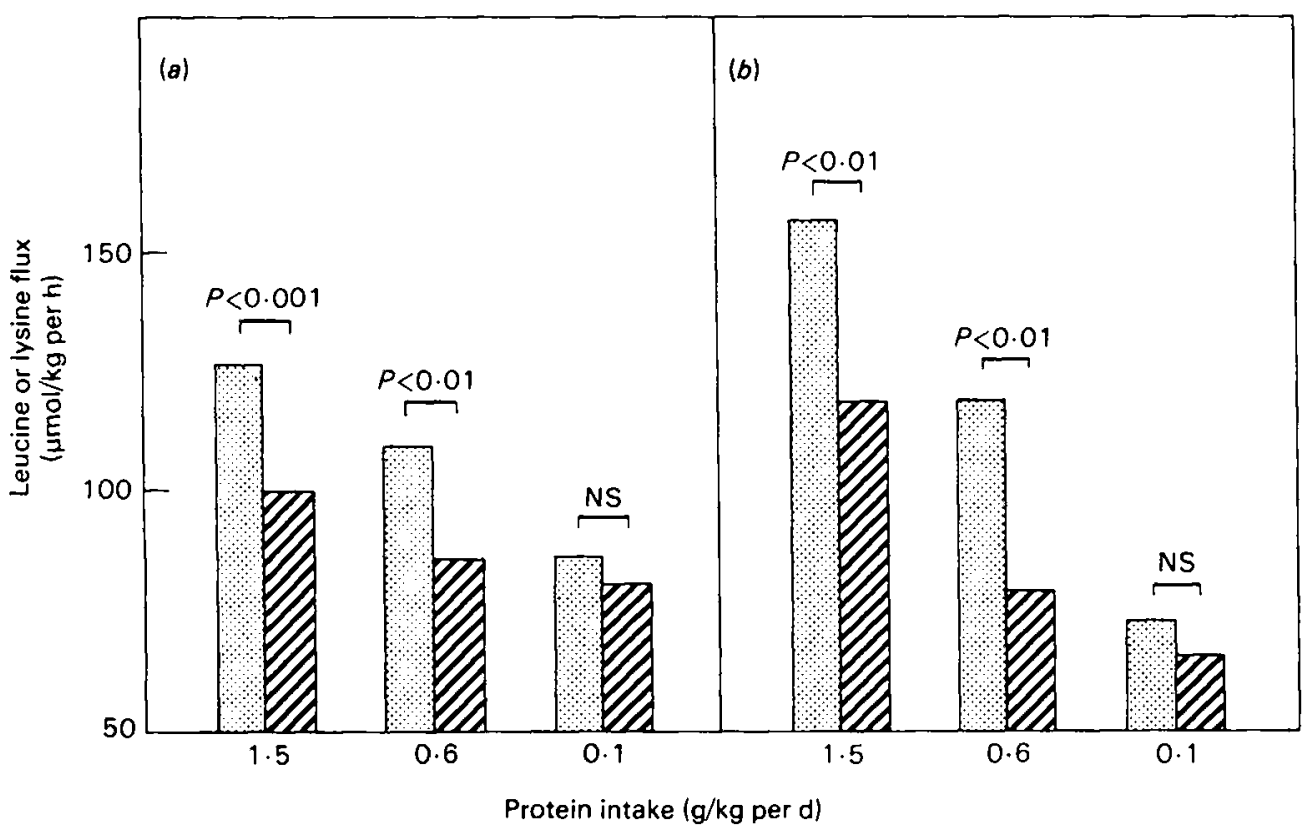

Fig. I. Comparison of whole body fluxes for leucine (国) and lysine (ש) in young men, studied while in the $(a)$ fasted and $(b)$ fed (post-absorptive states, receiving three levels of dietary protein. Drawn from Motil, Matthews et al. (1981). 
breakdown) to these changes in protein intake is given in Table 2. Rates of oxidation and incorporation of leucine into body proteins changed with altered protein intakes. For the post-absorptive state, an increase in dietary protein, from the requirement to generous intake level, was associated with an increased incorporation of leucine into body proteins, accounting for $100 \%$ of the change in flux. During the fed condition, leucine oxidation was greatly increased, together with an increased rate of leucine incorporation into tissue proteins. On the other hand, reducing the protein intake from the requirement to an inadequate level was associated with a small decline in the oxidation rate of leucine but a marked change in the rates of leucine incorporation into and release from body proteins.

These responses are consistent with observations in rats showing higher rates of oxidation of indispensable amino acids when consumed in excess of needs of growth (e.g. Brookes et al. 1972; Tanaka et al. 1975; Kang-Lee \& Harper, 1977, 1978; Tanaka \& Ogura, 1980) or for maintenance in adult rats (Simon, Adam et al. 1978). They also suggest that more than one mechanism is responsible for the adaptive responses of whole-body leucine metabolism and of body $\mathrm{N}$ balance to changes in dietary protein intakes. Furthermore, it appears that the mechanisms are related to the total $\mathrm{N}$ and amino acid needs of the host. Therefore, at generous and excess levels of protein the major change observed in leucine metabolism is one of a marked increase in oxidation, seen especially in the fed state. On the other hand, within the sub-maintenance-to-maintenance range alterations in dietary

Table 2. Rates of whole-body leucine oxidation, incorporation into proteins and release from proteins via protein breakdown ( $\mu \mathrm{mol} / \mathrm{kg}$ per $h$ ) in young men receiving three levels of protein intake, for the fed and post-absorptive states*

(Values are means with their standard errors for four subjects/group)

Protein intake level ( $\mathrm{g} / \mathrm{kg}$ per $\mathrm{d})$

$\quad \begin{aligned} & \text { Metabolic } \\ & \text { condition }\end{aligned}$
Post-absorptive:
Flux
Oxidation
Incorporation into protein
Release from protein
Fed : :
Flux
Oxidation
Incorporation into protein
Release from protein
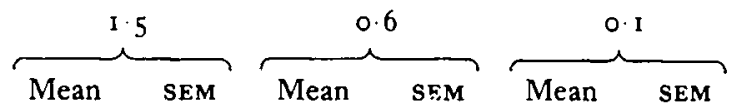

ost-absorptive:

Flux

Oxidation

$127 \cdot 4$

$3 \cdot 7$

$109 \cdot 7$

$2 \cdot 2$

$86 \cdot 8$

$5 \cdot 3$

17.6

$4 \cdot 7$

$22 \cdot 4$

$2 \cdot 7$

I $2 \cdot 9$

$76 \cdot x$

$2 \cdot 2$

I I $3 \cdot$ I

$3 \cdot 7$

89.3
107.4

$2 \cdot 4$

$84 \cdot 5$

$3 \cdot 8$

$157 \cdot 3$

$7 \cdot 8$

I $19 \cdot 7$

$6 \cdot I$

$72 \cdot 7$

$46.3 \quad 3.8$

$2 I \cdot 6$

I. I

I I. 8

$5 \cdot 3$

I $3.3 \quad 6.7$

$102 \cdot 4$

$7 \cdot 6$

$67 \cdot 2$

$7 \cdot 9$

$82 \cdot 3$

$64 \cdot 4$

2. 8

- From Motil, Bier et al. ( 1981 ).

†The fed state was achieved by offering subjects, at hourly intervals, isoenergetic isonitrogenous meals each equivalent to one-twelfth of the daily protein and energy intake and beginning $\mathrm{i}$ h prior to isotope infusion and $3 \mathrm{~h}$ following their usual breakfast. 
protein intake bring about changes in leucine metabolism that are principally related to a reduced body protein turnover.

These dietary-induced changes in whole body leucine kinetics can be modulated by the energy status of the host and the level of energy intake. Thus, we have also examined the possible basis for changes in $\mathrm{N}$ balance when energy intakes exceed requirements (Motil, Bier et al. 1981). For this purpose, we chose a dietary protein intake level of $0.6 \mathrm{~g} / \mathrm{kg}$ per $d$ to explore responses of whole body leucine and lysine metabolism to excess intakes of dietary energy from the different energy sources. Maintenance energy intakes averaged $44 \mathrm{kcal} / \mathrm{kg}$ per d, comparable to an adequate energy intake for healthy adult men (FAO/WHO, 1973). The excess level supplied a $25 \%$ increment above the maintenance need.

As summarized in Table 3, $\mathrm{N}$ balance improved with excess dietary energy intake and the response was somewhat greater for those diets containing an excess of carbohydrate (e.g. see also Munro, 1964). However, these changes in $\mathrm{N}$ retention were not associated with any dramatic changes in whole body leucine flux (Table 3). Nevertheless, when the small changes in whole body leucine kinetics in response to excess energy are used to compute net leucine retention (leucine incorporation into proteins minus leucine liberated by protein breakdown) this parameter was found to be higher for the fed state when dietary energy intake exceeded maintenance needs. Furthermore, diets containing a relatively higher carbohydrate content were associated with a greater change in net leucine retention than those based on fat as the source of additional energy (Motil, Bier $e t$ al. $\mathrm{x} 98 \mathrm{r})$.

Daily $\mathrm{N}$ balance was increased by an average of about $22 \mathrm{mg} \mathrm{N} / \mathrm{kg}$ per $\mathrm{d}$ when energy intake was raised above the requirement level. Thus, assuming body protein contains $3.7 \mathrm{mmol} / \mathrm{g} \mathrm{N}$ (Waterlow et al. 1978 ) this change is equivalent to

Table 3. Nitrogen balance and whole body leucine kinetics $(\mu \mathrm{mol} / \mathrm{kg}$ per $h$ ) in young adult men receiving maintenance and excess levels of dietary energy*

(Values are means with their standard errors for twelve subjects)

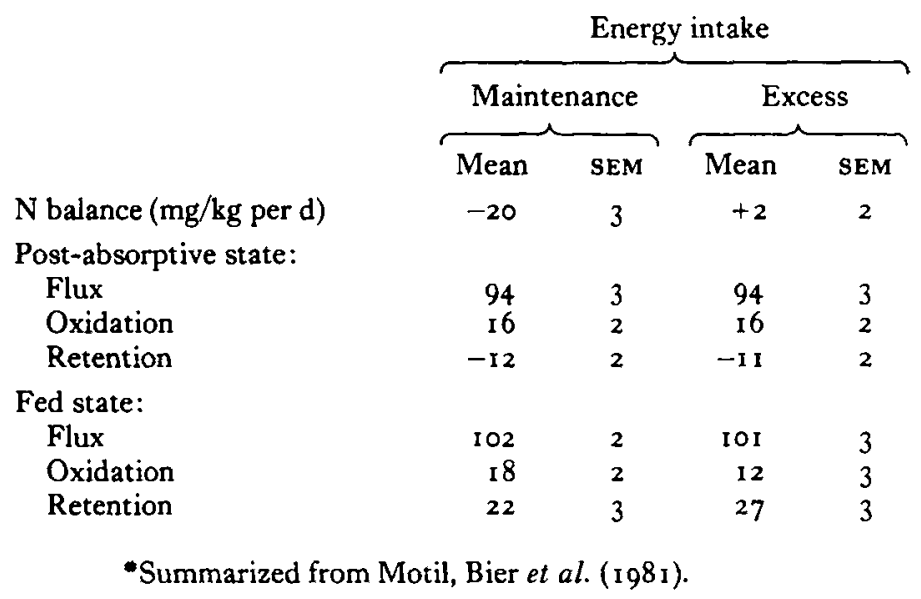


an increase in net leucine retention of about $8 \mathrm{I} \mu \mathrm{mol} / \mathrm{kg}$ per d. Alternatively, it can be also assumed that the daily retention of leucine is the average of the difference between the rates of leucine inflow into the metabolic pool by protein breakdown and leucine outflow via protein synthesis during the post-absorptive and fed states. Estimated in this way net leucine retention differed between diets providing maintenance and excess energy by approximately $71 \mu \mathrm{mol} / \mathrm{kg}$ per $\mathrm{d}$. This general agreement between the $\mathrm{N}$ balance results and those based on leucine kinetics emphasize that significant changes in body $\mathrm{N}$ balance can be brought about by only relatively small alterations in the fate of leucine, and of other amino acids, that enter tissue amino acid pools.

The above findings reveal that the major pathways of leucine metabolism are affected by alterations in the dietary protein and energy supply and, furthermore, that they co-ordinately respond to promote whole body leucine homoeostasis. However, the responses of the metabolism of the dispensable amino acids are also important when the over-all maintenance of the $\mathrm{N}$ economy of the host is considered.

Using a model, previously described (Gersovitz et al. 1980), to estimate the rate of whole body glycine synthesis we have observed, as shown in Fig. 2, that this is reduced in healthy young adult and elderly men when these subjects receive a diet

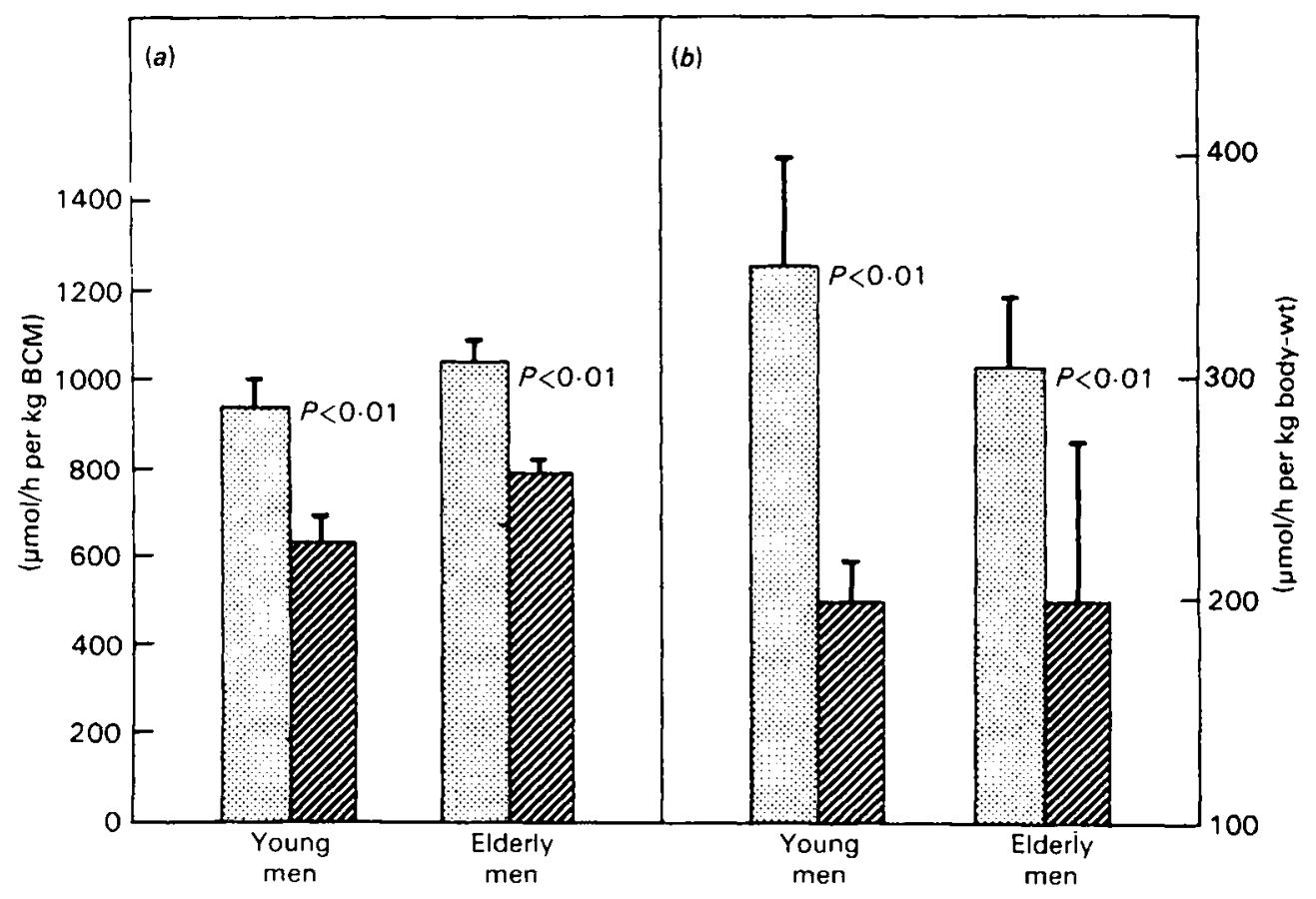

Fig. 2. Whole body glycine flux $(a)$ and rate of de novo glycine synthesis $(b)$ in young adult and

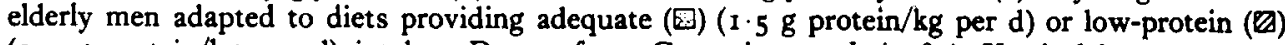
$(0.4 \mathrm{~g}$ protein $/ \mathrm{kg}$ per d) intakes. Drawn from Gersovitz et al. (rg80). Vertical bars represent standard errors. 
supplying a protein intake level that is lower than the maintenance requirement. These observations also suggest that there is an extensive flux of $\mathrm{N}$ along pathways associated with the metabolism of dispensable amino acids. For this reason it is necessary to expand the picture of whole body amino acid kinetics to include the metabolism of other dispensable amino acids and their responses to altered nutritional states. Thus, we have also begun to study whole body alanine metabolism to changes in protein intake in young men. The model used for this purpose is shown in Fig. 3 and a summary of our preliminary findings is presented in Fig. 4. In contrast to the changes already noted in whole body glycine synthesis, the rate of formation of alanine is not reduced when protein intake is restricted within intakes ranging from a generous to an essentially protein-free level. Indeed, as depicted in Fig. 4, alanine synthesis was higher at the lower protein intakes. Furthermore the ingestion of meals stimulated the formation of alanine (Fig. 4), due probably to ingestion of the major energy yielding nutrients (carbohydrate), since this response to meal feeding was similar for diets providing quite different protein contents. In view of the significance of alanine in whole body glucose (Felig, 1973) and N metabolism (Chochinov et al. 1978), it is evident that further studies of alanine metabolism under various dietary conditions would be instructive.

From the foregoing, it appears that the dynamic responses of the metabolism of specific amino acids, and of whole body proteins, to changes in protein intake

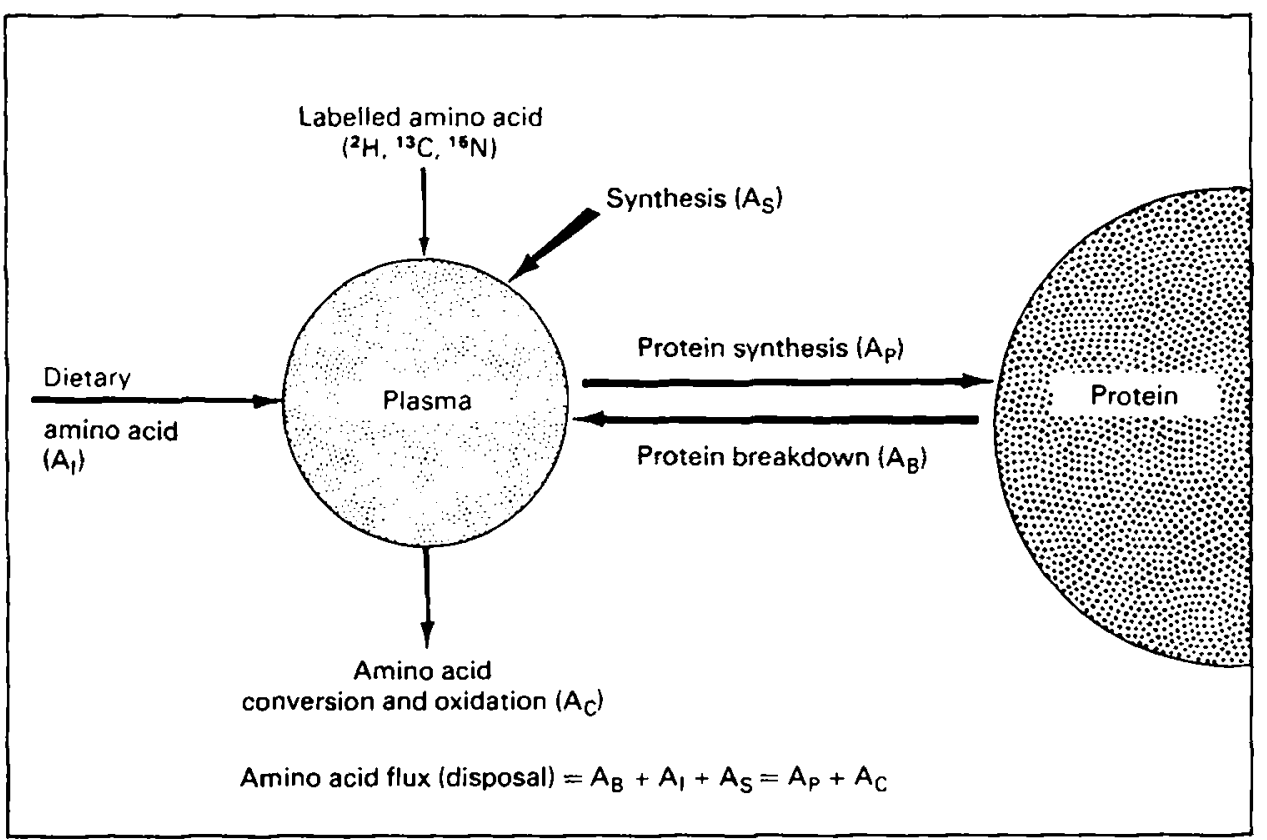

Fig. 3. Model used to estimate whole body flux and de novo synthesis of a dispensable amino acid, such as alanine or glycine. 


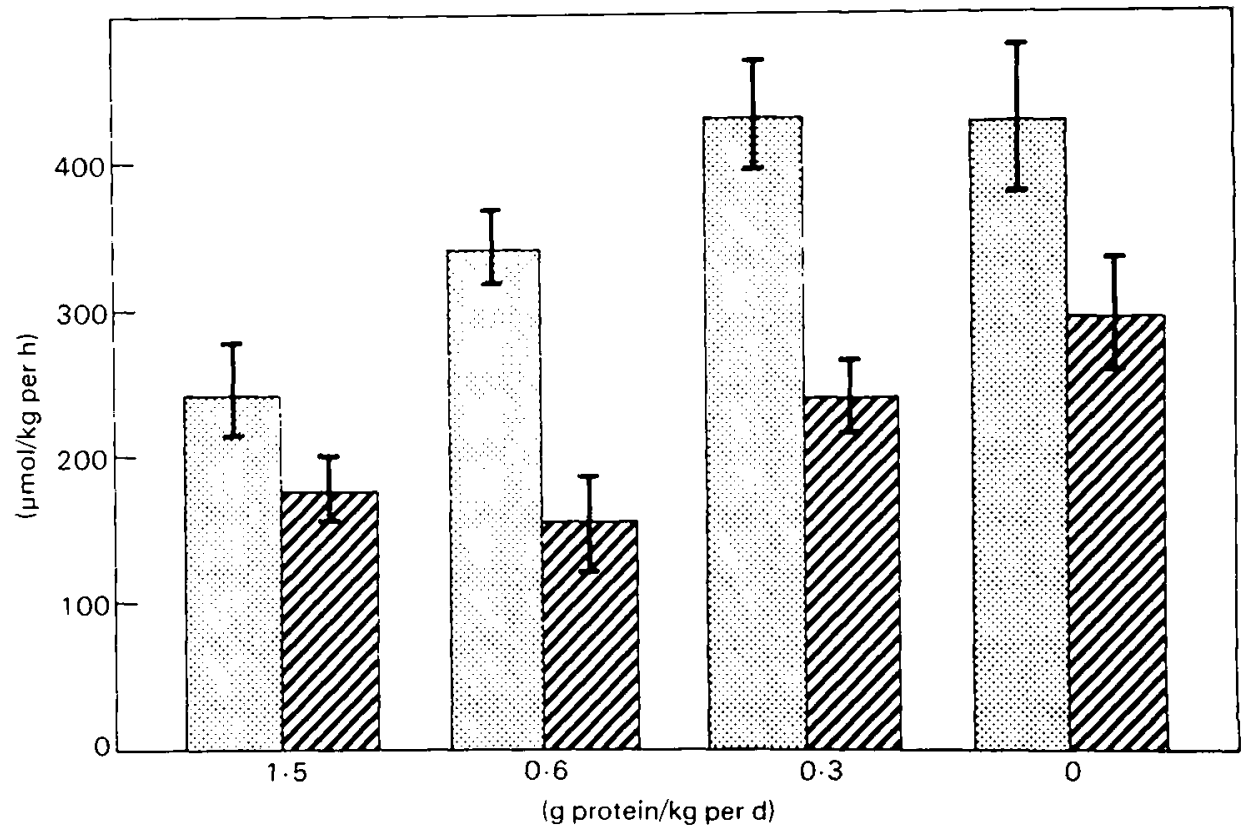

Fig. 4. Rate of de novo alanine synthesis in young men, studied in the post-absorptive ( $(\mathbb{D})$ and fed (圈) states, after receiving diets that supplied various levels of protein for $7 \mathrm{~d}$. Unpublished results of $\mathrm{R}$. Yang et al.

might be differentiated for those intakes of protein or specific amino acids or both that are generous, on the one hand, and for intakes that are within the submaintenance range, on the other hand. If this is so, it should be possible to examine whole body amino acid kinetics in a way that might have predictive value in the study of human protein and amino acid requirements. We will now consider this possibility.

\section{Amino acid metabolism in relation to requirements}

Many of the estimates of human amino acid requirements are based on results obtained from metabolic $\mathrm{N}$ balance studies (e.g. see Irwin \& Hegsted, I97I). The limitations of the earlier balance studies and the estimates of requirements derived from them are well recognized (e.g. Hegsted, 1963; Young \& Scrimshaw, 1978) and we have turned to the application of stable isotope tracer approaches for purposes of further evaluating current estimates of the requirements for indispensable amino acids in healthy young men (Young, Meguid et al. 1981). First, from a series of unpublished MIT studies, in which volunteer subjects were given diets based on L-amino acid mixtures, we can compare estimates of whole body protein synthesis for diets providing all nutrients in adequate amounts with those obtained when the intake of a specific indispensable amino acid approximates a level thought to be sufficient to meet the requirement for protein nutritional maintenance. These comparisons are summarized in Table 4 and they show that the rate of whole body protein synthesis is reduced when 'requirement' levels of the 
Table 4. Rates of protein synthesis, expressed as amino acid incorporation ( $\mu \mathrm{mol} / \mathrm{kg}$ per h), in young men receiving L-amino acid diets providing a generous or 'requirement' intake of specific amino acids"

(Values are means with their standard errors for the rate of incorporation into whole body protein; values in parentheses give the daily intake of the amino acid ( $\mathrm{mg} / \mathrm{kg}$ per d))

$\begin{array}{ccccc}\text { Amino } & \overbrace{\text { Mean }}^{\text {Generous }} & & \text { SEM } & \overbrace{\text { Mean }}^{\text {'Requirement' }} \\ \begin{array}{ccccc}\text { acid } \\ \text { Lysine }\end{array} & \text { I08 } & \text { I (100) } & 49 & 5(12) \\ \text { Valine } & 99 & 6(68) & 46 & 2(12) \\ \text { Leucine } & 89 & 8(79) & 59 & 4(12)\end{array}$

-Based on unpublished MIT work of Meguid and Meredith and obtained using a constant intravenous infusion of the $\mathrm{L}-\mathrm{I}-{ }^{13} \mathrm{C}$-amino acid.

amino acid are consumed. Furthermore, these lower rates of synthesis are less than those obtained with subjects receiving adequate intakes of protein (see Waterlow et al. 1978). Although we do not know what the appropriate rate for whole body protein synthesis rates might be, in reference to a maintenance of an adequate level of health and physiologic function, these observations suggest that the current requirement values for specific indispensable amino acids may not be sufficient to maintain a 'normal' state of protein turnover.

To examine this problem further, we have measured whole body amino acid oxidation rates and protein turnover at intake levels of specific indispensable amino acids in the regions both above and below the requirement level for maintenance of protein nutritional status (i.e. $\mathrm{N}$ balance). Results are shown in Fig. 5 for lysine oxidation in young men receiving graded intakes of this amino acid and in Fig. 6 for the rate of incorporation of leucine into whole body protein for subjects receiving graded intakes of leucine. From these preliminary results it is apparent that marked changes in these response curves occur in the intake region of 30 $\mathrm{mg} / \mathrm{kg}$ per $\mathrm{d}$ for lysine and $23 \mathrm{mg} / \mathrm{kg}$ per $\mathrm{d}$ for leucine.

It is significant that these responses of whole body lysine and leucine metabolism observed in healthy adult humans are similar to those reported from studies in growing and adult rats (Kang-Lee \& Harper, 1977, 1978; Simon, Adam et al. 1978; Tanaka \& Ogura, 1980). These responses of amino acid metabolism in rats have been used to estimate the dietary requirement for specific indispensable amino acids. Our comparable data based on whole body amino acid dynamics in healthy young men, suggest, therefore, that the current estimates of adult amino acid requirements (e.g. FAO/WHO, 1973) might be deficient and that an adequate level of amino acid intake for protein nutritional maintenance is best predicted from changes in whole body amino acid dynamics to altered amino acid intakes (Young, Meguid et al. 198I). Although we recognize that this assessment of our findings must be considered tentative, these data support the reservations that we 


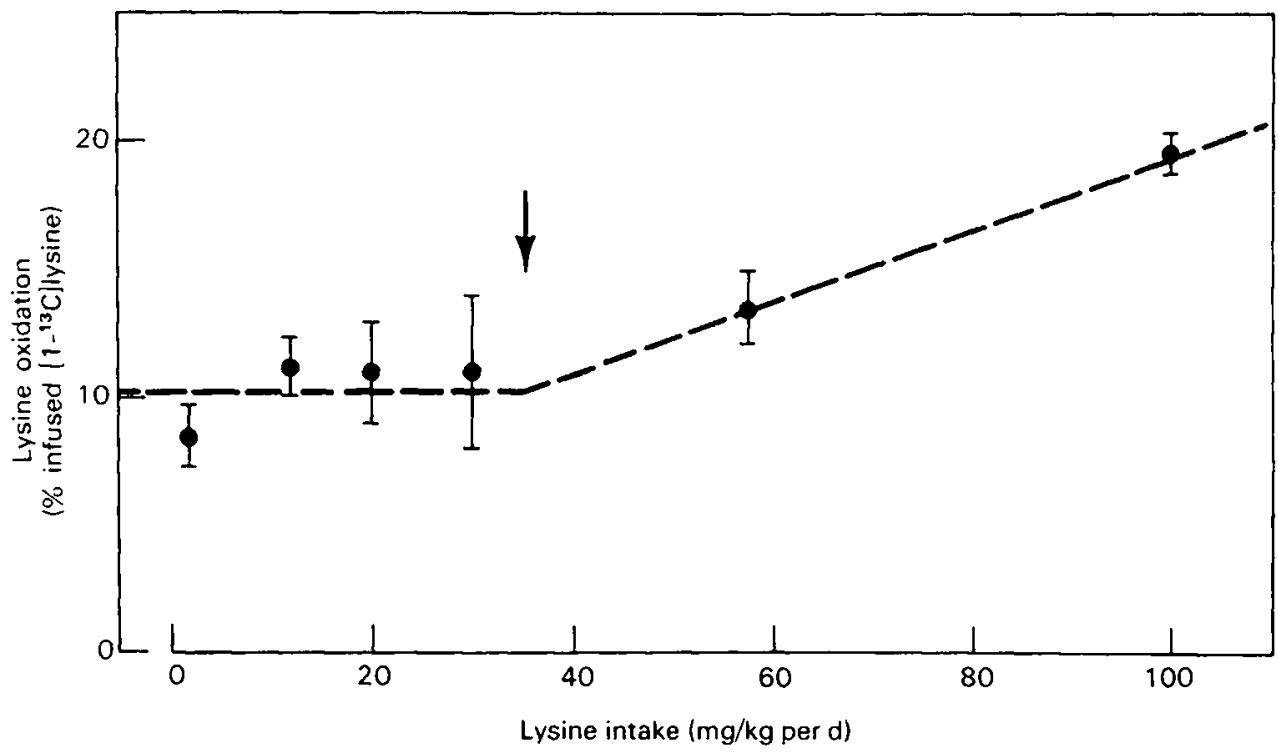

Fig. 5. Lysine oxidation, determined with a primed constant intravenous infusion of $\left[\mathrm{I}^{13} \mathrm{C}\right] \mathrm{ysine}$, in young men after receiving graded intakes of lysine from an L-amino acid diet. Preliminary results of Meredith et al. Lines drawn by inspection. Points are means with their standard errors represented by vertical bars.

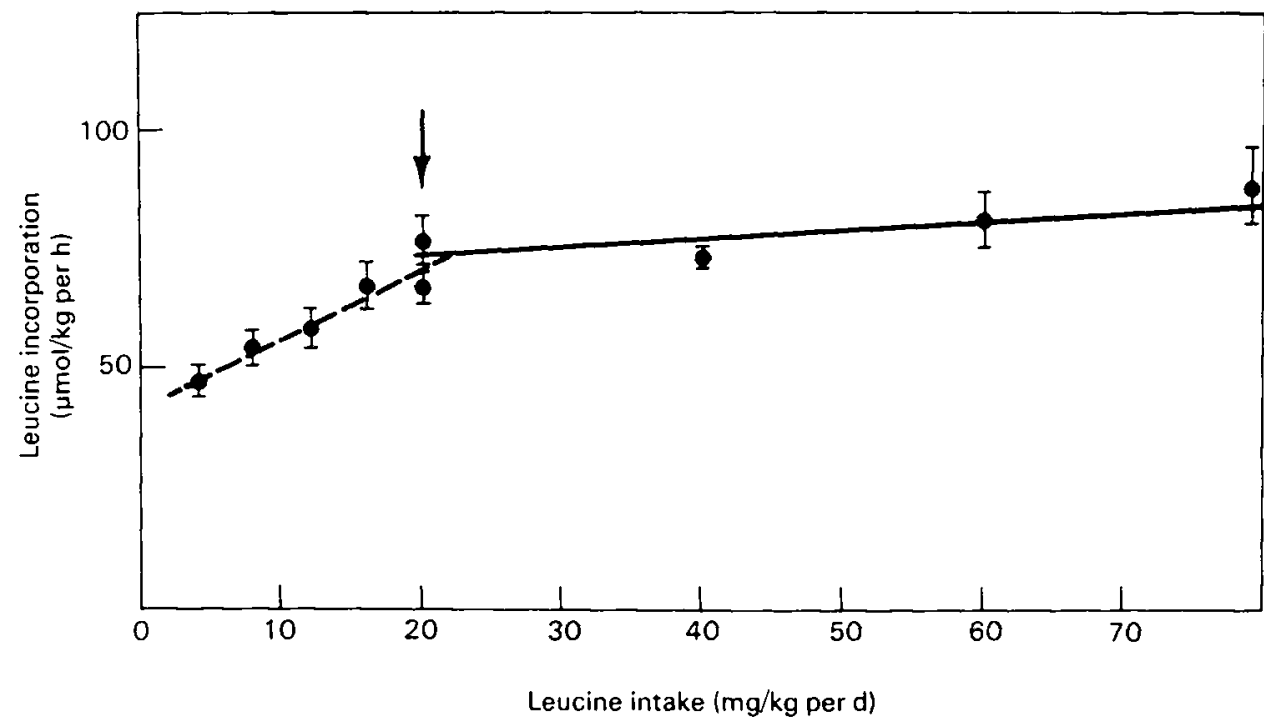

Fig. 6. Rate of incorporation of leucine into whole body proteins, as determined with a primed-constant intravenous infusion of $\left[\mathrm{L}-\mathrm{x}-{ }^{13} \mathrm{C}\right]$ leucine, in young men receiving graded intakes of leucine from an L-amino acid diet. Preliminary results of Meguid et al. Points are means with their standard errors represented by vertical bars. 
have expressed previously (Young \& Scrimshaw, 1978; Young, Meguid et al. 1981) about the uncertainty of the nutritional significance of the published requirements for indispensable amino acids in adults.

Finally, we must point out that we do not know whether the appropriate criterion to evaluate human amino acid requirements should be that based on a measure of amino acid oxidation rates or whole body amino acid flux or the rates of whole-body protein synthesis and breakdown. Furthermore, the specific criterion might differ with the specific amino acid in question. For example, studies in rats show that the change in the oxidation rate of methionine is linear throughout a broad range of methionine intake, both above and below the requirement level (Aguilar et al. 1974). This contrasts with the 'breakpoint' type of response observed for the oxidation of lysine, histidine and threonine (Brookes et al. 1972; Kang-Lee \& Harper, 1977, 1978; Simon, Adam et al. 1978), to graded intakes of these specific amino acids over this same range. Therefore, the relationship between methionine intake, whole body amino acid dynamics and the methionine requirement of human subjects might be explored more usefully by studying changes in whole body protein synthesis or breakdown rates or methionine flux. On the other hand, a determination of the rate of lysine oxidation at various lysine intakes might be a more appropriate technique for establishing the requirement for this particular amino acid. This problem can be resolved only through a more extensive investigation of comparative and quantitative aspects of whole body metabolism for specific indispensable amino acids in human subjects under various conditions of protein and amino acid intake.

As reviewed in more detail (Young, Meguid et al. 1981) these studies of whole body amino acid kinetics suggest that the amino acid requirements of healthy adult men may have been significantly underestimated. If this is actually so, the precise interpretation of the effects of disease states on amino acid requirements cannot be judged precisely yet without a more definitive definition of the amino acid requirements in healthy people. Finally, in this particular context, hospitalized patients may receive exogenous energy substrate and amino acids via peripheral or central veins. This mode of nutrient administration introduces additional questions regarding the responses of human protein and amino acid metabolism to altered inputs of nutrients and their requirements. Hence, a final topic to be discussed briefly concerns some recent findings that relate to this aspect of protein metabolism and nutritional state.

\section{Response of amino acid metabolism to intravenous glucose administration}

The central role of alanine in the metabolic cycles in the skeletal muscles and their inter-relationships with gluconeogenesis in the liver, particularly under conditions of fasting, have led to the concept of a glucose-alanine cycle that operates to maintain glucose homoeostasis when exogenous supply of energy is restricted (Felig, r 973). However, there is doubt about the quantitative significance of sources of the carbon for alanine (see Goldberg \& Chang, 1978). Furthermore, there is a rapid exchange of carbon atoms between glucose, lactate and alanine 
(Foster et al. 1980). More recently, therefore, it has been suggested that the specific physiological function of the glucose-alanine cycle may be more concerned with ammonia or $\mathrm{N}$ transport (Chochinov et al. 1978) than with glucose homoeostasis per se. Indeed, Lund (198I) has concluded that alanine is a major precursor of urea $\mathrm{N}$. The associations among alanine, glucose and $\mathrm{N}$ metabolism are depicted in Fig. 7.

We have studied kinetic aspects of whole body alanine and glycine metabolism in young men while they were in the post absorptive state and their response to an intravenous glucose infusion. This study was performed with the aid of a continuous administration, by vein, of the amino acids labelled with ${ }^{15} \mathrm{~N}$ or ${ }^{2} \mathrm{H}$ and application of the model described above (Fig. 2). Thus, by combining infusions of labelled alanine or glycine with $\left[\mathrm{I}^{-13} \mathrm{C}\right]$ leucine or $\left[\mathrm{I}^{-13} \mathrm{C}\right] \mathrm{lysine}$, respectively, to estimate the rate of body protein breakdown, we have been able to calculate the de novo rates of synthesis of each of these dispensable amino acids. As summarized in Table 5, the synthesis of new alanine and glycine molecules accounts for about $60-70 \%$ of the whole body fluxes of the amino acids. Also, it is worth pointing out that the estimates of alanine flux given in this table agree with earlier values based on the use of ${ }^{14} \mathrm{C}$-alanine (Chochinov et al. 1978 ) and alanine-2, $d_{1}-3,3,3, d_{3}$ (Bier et al. 1977) in healthy post-absorptive adult subjects.

When glucose was infused by vein at a rate of $4 \mathrm{mg} / \mathrm{kg}$ per min, which resulted

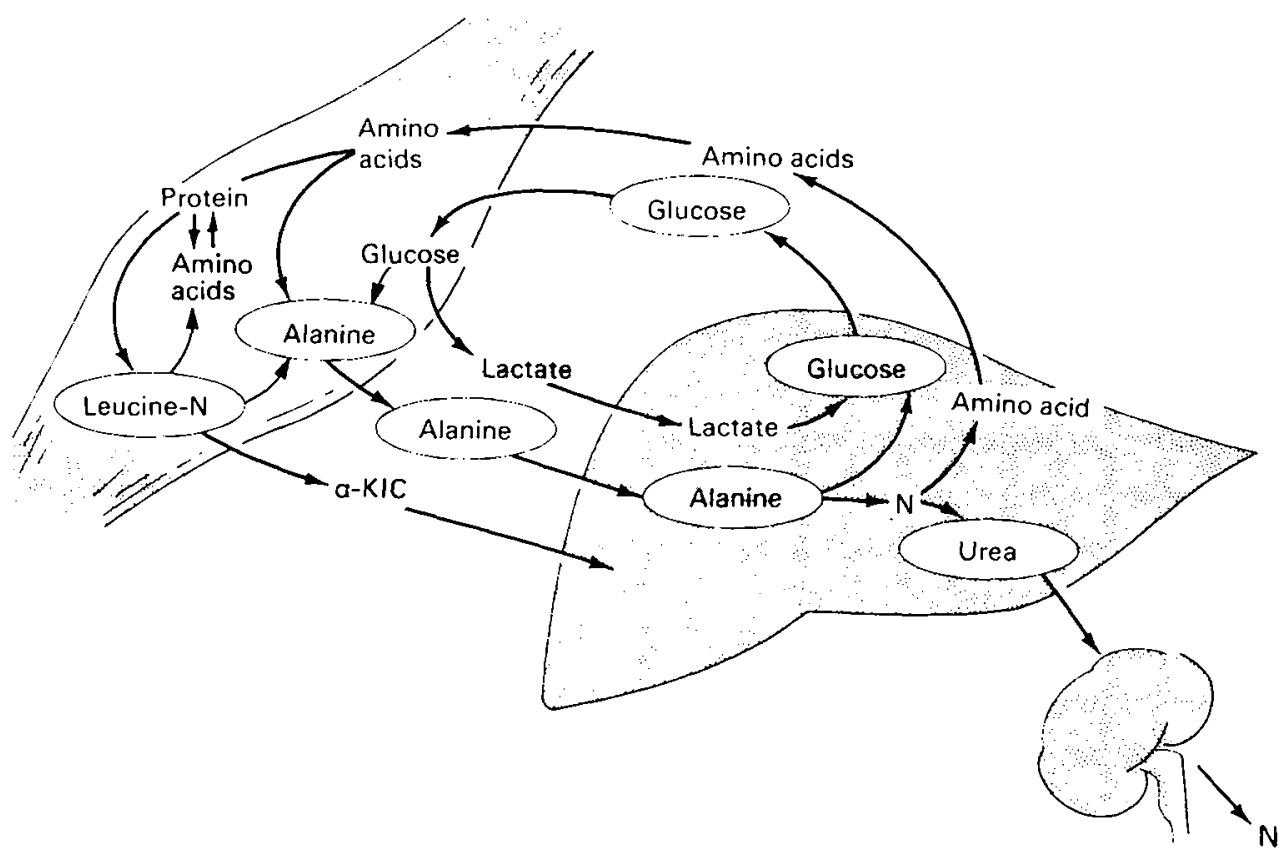

Fig. 7. Schematic outline of associations among alanine, amino acid, glucose and nitrogen metabolism with an indication of the roles played by skeletal muscles and the liver in these interrelationships. 
Table 5. Alanine and glycine fluxes and de novo synthesis rates $(\mu \mathrm{mol} / \mathrm{kg}$ per $h)$ in post-absorptive young men*

(Values are means with their standard errors; values in parentheses give the percentage flux)

\begin{tabular}{|c|c|c|c|c|c|}
\hline & \multicolumn{2}{|c|}{ Alanine } & & \multicolumn{2}{|c|}{ Glycine } \\
\hline & Mean & SEM & & Mean & SEM \\
\hline Flux: & 353 & 35 & & 240 & 22 \\
\hline From protein breakdown & 104 & 4 & $(22 \pm 3)$ & 96 & I 2 \\
\hline De novo synthesis & 277 & 29 & $(72 \pm 3)$ & 144 & 13 \\
\hline
\end{tabular}

"From Robert (198r).

in a significant hyperglycemia and an increased plasma insulin concentration (Fig. 8), the alanine flux was significantly increased but glycine flux did not change (Fig. 9). For alanine this rise was entirely due to an enhanced rate of synthesis of new alanine molecules. The mean increase in alanine synthesis was $101 \mu \mathrm{mol} / \mathrm{kg}$ per $\mathrm{h}$ and if derived entirely from glucose, this would account for an additional conversion of $50 \mu \mathrm{mol}$ of the infused glucose. This represents about $7 \%$ of the additional glucose disposal when glucose is administered at a rate of $4 \mathrm{mg} / \mathrm{kg}$ per min (Robert, 1981). In agreement with this finding, it has been reported that in perfused muscle preparations less than $3 \%$ of the uptake of glucose was converted to alanine (Grubb, 1976). Thus, we can conclude that while glucose may be the

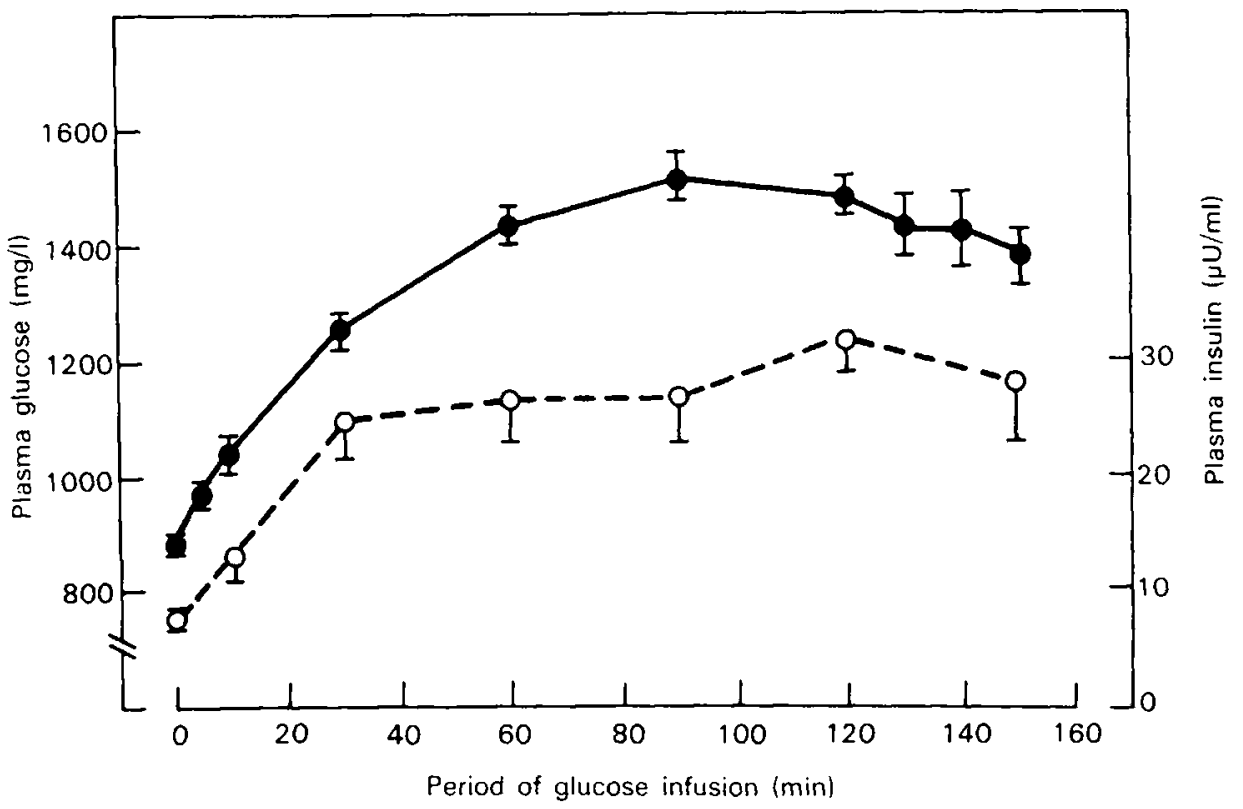

Fig. 8. Change in plasma glucose $(-\circ)$ and in insulin $\left(\mathrm{O}_{-}-\mathrm{O}\right)$ concentrations in postabsorptive young men during an intravenous infusion of glucose at $4 \mathrm{mg} / \mathrm{kg}$ per min. Unpublished results of J.-J. Robert et al. Points are means with their standard errors represented by vertical bars. 

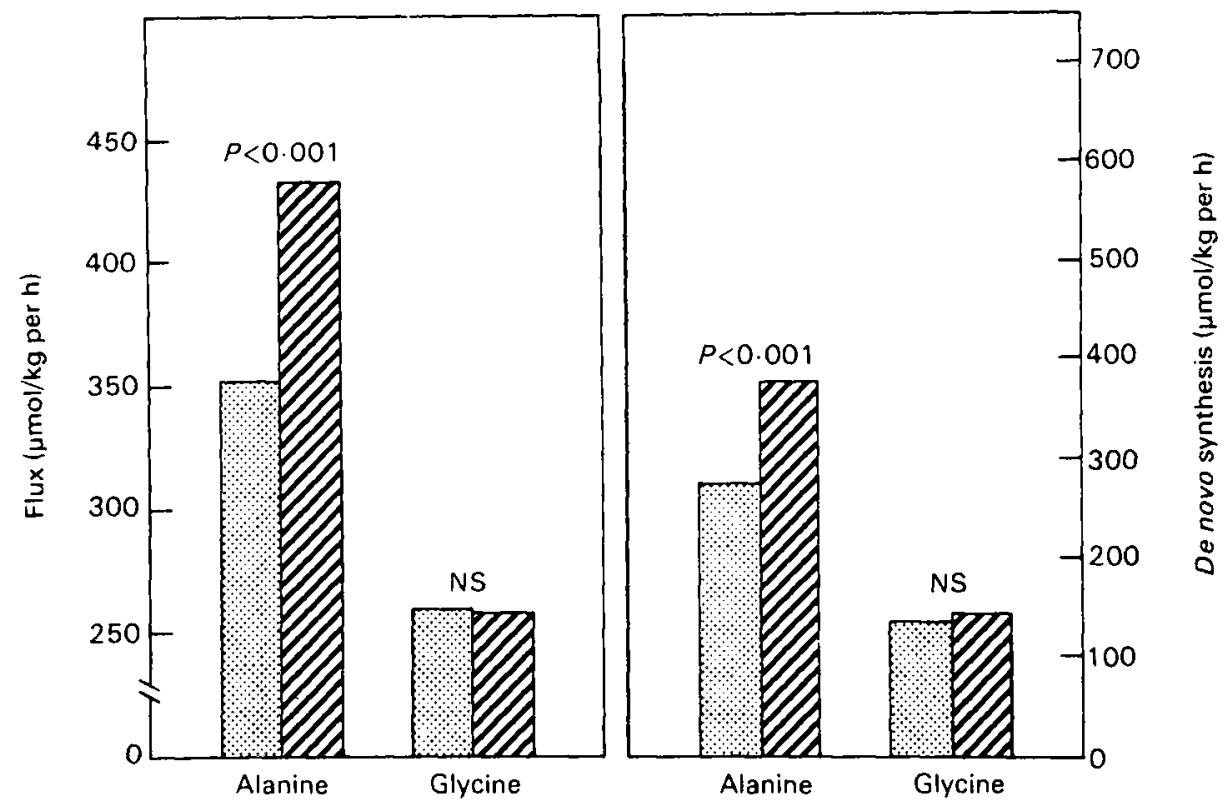

Fig. 9. Fluxes of alanine and glycine and their rates of synthesis before (⿴囗大) and after (Z) an intravenous infusion of $4 \mathrm{mg} / \mathrm{kg}$ per min glucose in young men. Unpublished results of J.-J. Robert et al.

most important source of carbon for alanine synthesis, it represents a quantitatively minor pathway of total glucose disposal in the post-absorptive state or during a brief period of glucose infusion.

These findings raise an intriguing speculation in that a hyperglycaemic state, coupled with a moderate increase in circulating insulin, might drive the synthesis of alanine and its subsequent release from skeletal muscles and possibly other tissues, such as the intestine. If this occurs under conditions where the coordinated regulation of metabolic pathways is altered by stress or disease, the increased rate of alanine synthesis could lead to a depletion of $\mathrm{N}$ in muscles and the body as a whole if the $\mathrm{N}$ from alanine is subsequently transferred to urea during its metabolism in the liver (Lund, $198 \mathrm{r}$ ). In partial support of this speculation, which is described in schematic form in Fig. 10, are the observations showing increased rate of alanine output by muscles during physical exercise (Felig \& Wahren, 1971) and that this is apparently associated with enhanced rates of urea production (Lemon \& Mullin, I980). Possibly, therefore, the hyperglycaemia typical of injury or sepsis (Beisel \& Wannemacher, I 980), coupled with an enhanced rate of glucose disappearance from plasma (Wolfe et al. 1979), might be of causal significance in the wasting of body $\mathrm{N}$ under stressful conditions (Cuthbertson, 1964). If this hypothesis is valid, therapy aimed at reducing alanine formation might improve the $\mathrm{N}$ balance status of patients exposed to these unfavourable situations. However, there are many issues that need examination in this context: first, for example, alanine production rates have not been found to be higher in diabetic patients (Hall et al. 1979). However, in the studies of Hall et al. (1979) ketone 

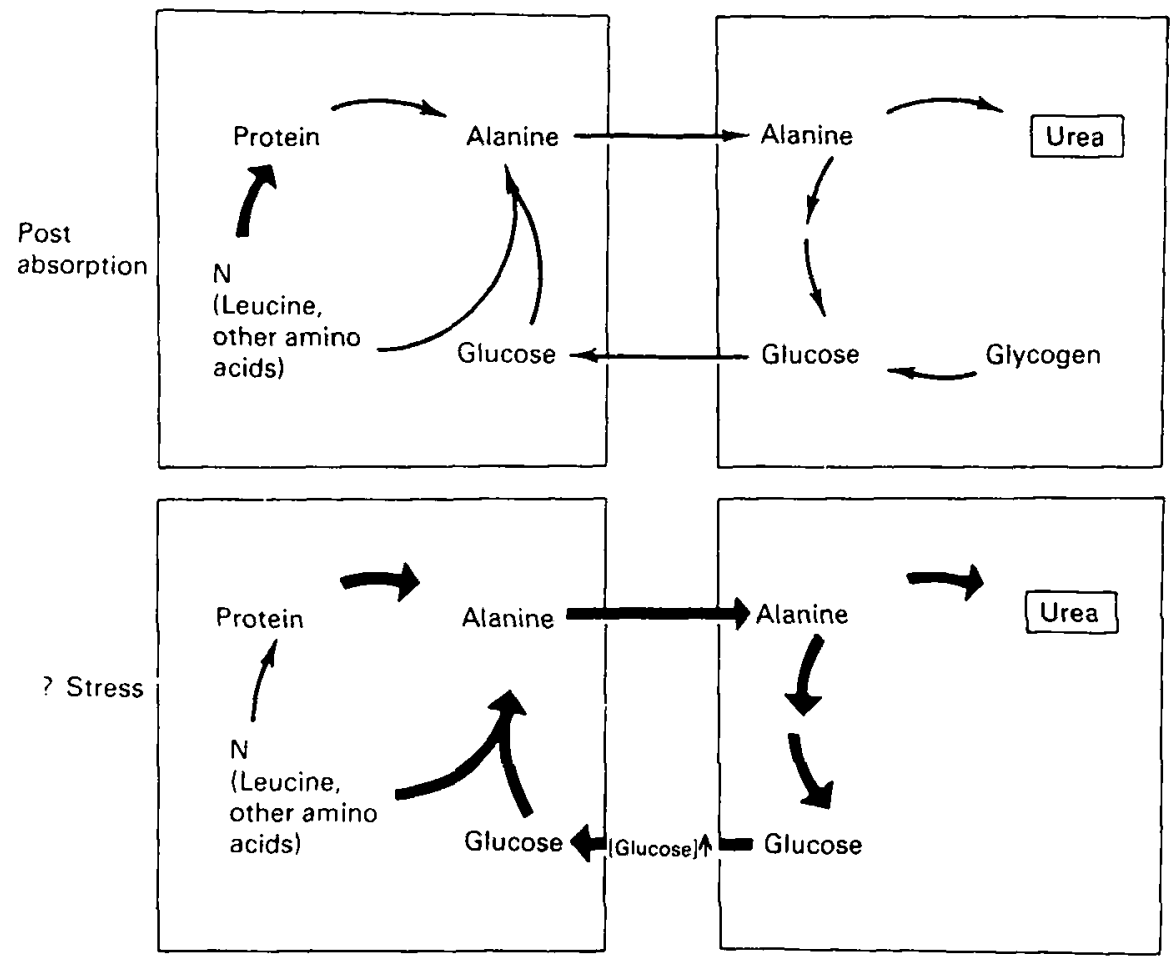

Fig. 10. A speculative outline of the metabolic interrelationships between alanine, glucose and urea metabolism in the normal state and during conditions of stress. This latter condition is associated with increased glucose turnover and urea $\mathrm{N}$ output consequent to an enhanced alanine synthesis.

body levels were high in their diabetic patients and it has been suggested that ketone bodies might reduce alanine formation (Sherwin et al. 1975). It is pertinent, then, that Williamson et al. (1977) reported a lower rate of both $\mathrm{N}$ loss in patients following physical trauma where they developed a ketonaemia, as compared with those patients who showed only a small rise in blood ketone levels. Secondly, an intravenous infusion of glucose in healthy subjects improves body $\mathrm{N}$ balance (Wolfe et al. 1977) and the rise in alanine synthesis that we found in our study was probably not associated with an absolute increase in urea $\mathrm{N}$ excretion. The $\mathrm{N}$ sparing effect of glucose is well-recognized so that in healthy subjects the increased alanine synthesis due to glucose administration does not necessarily compromise body $\mathrm{N}$ balance. However, the normal regulation of gluconeogenesis is affected by the septic or stressed state (Long et al. 1976; Beisel \& Wannamacher, I980) and it is possible that in these conditions an enhanced rate of urea formation would accompany a rise in alanine synthesis, limiting the efficiency of retention of $\mathrm{N}$ from endogenous or exogenous sources. In any event, an exploration of our speculative involvement of alanine metabolism in the causation of stress-induced body $\mathrm{N}$ 
losses should be expected to provide a better understanding of the mechanisms responsible for maintenance of body $\mathrm{N}$ economy and how they are altered in disease states.

\section{Conclusion}

In this brief review of results of some of our recent studies, we have identified a number of intriguing and significant problems concerned with the maintenance of body protein and amino acid metabolism under various nutritional conditions. We believe that stable isotope probes, coupled with an improvement in the models applied, offer an exciting means for gaining new insights into the physiology of protein and amino acid metabolism and possibly an improved definition of the quantitative requirements for $\mathrm{N}$ and dispensable amino acids in human nutrition.

The authors' studies described herein were supported by NIH grants $\mathrm{AM}_{1} 5_{5}{ }_{5} 6$, AG-0 1 48I, and USDA grant No. 590I-0410-8-006X-0. We are most appreciative of the contributions made to our research advances by Drs D. Matthews, K. Motil, J.-J. Robert, R. Wolfe, J. Hoffer, M. Meguid, X. Zhao, and Z. Wen; Mr R. Yang and Ms C. Meredith.

\section{REFERENCES}

Aguilar, T. S., Benevenga, N. J. \& Harper, A. E. (1974). F. Nutr. ro4, 761.

Beisel, W. R. \& Wannemacher, R. W. (rg80). $\mathcal{Y} P E N$ 4, 277.

Bier, D. M., Arnold, K. J., Sherman, W. R., Holland, W. H., Holmes, W. F. \& Kipnis, D. M. (1977). Diabetes 26, 1005.

Brookes, I. M., Owen, F. N. \& Garrigus, U. S. (1972). F. Nutr. 102, 27.

Calloway, D. H. (1975). F. Nutr. 105, 914 .

Chochinov, R. H., Perlman, K. \& Moorhouse, J. A. (1978). Diabetes $27,287$.

Cuthbertson, D. P. (I964). In Mammalian Protein Metabolism, vol. II, Chpt. I9, p. 373 [H. N. Munro and J. B. Allison, editors]. New York: Academic Press.

Dean, R. T. (1980). In Biochemistry of Cellular Regulation, vol. II, Chpt. 5, p. IOI [M. Ashwell, editor]. Boca Raton, Florida: CRC Press, Inc.

Elwyn, D. H., Gump, F. R., Munro, H. N., Iles, M. \& Kinney, J. M. (1979). Am. f. clin. Nutr. 32, I 597.

FAO/WHO (1973). WHO Tech. Rept. Ser. No. 522. Geneva: World Health Organization.

Felig, P. (1973). Metabolism 22, 179.

Felig, P. \& Wahren, J. (1971). F. clin. Invest. 50, 2703.

Foster, D. M., Hetenyi, G. \& Berman, M. (1980). Am. F. Physiol. 239, E3o.

Garlick, P. J. (1980). In Comprehensive Biochemistry, vol. I gB, Part I, Chpt. 2, p. 77 [M. Florkin, A. Newberger and L. L. M. Van Deenen, editors]. Amsterdam: Elsevier-North Holland Biomed Press.

Garlick, P. J., Clugston, G. A., Swick, R. W. \& Waterlow, J. C. (1980). Am. F. clin. Nutr. 33, I 983 .

Garza, C., Scrimshaw, N. S. \& Young, V. R. (1976). Am. F. clin. Nutr. $29,280$.

Garza, C., Scrimshaw, N. S. \& Young, V. R. (1977). Br. F. Nutr. 37, 403.

Garza, C., Scrimshaw, N. S. \& Young, V. R. (1978). F. Nutr. 108, 9o.

Gersovitz, M., Bier, D. M., Matthews, D., Udall, J., Munro, H. N. \& Young, V. R. (1980). Metabolism 29, 1087 .

Goldberg, A. L. \& Chang, T. W. (1978). Fedn Proc. Fedn Am. Socs exp. Biol. 37, 230 I.

Grubb, B. (1976). Am. F. Physiol. 230, 1379.

Hall, S. E. H., Braoten, J. T., McKendry, J. B. R., Bolton, T., Foster, D. \& Berman, M. (1979). Diabetes 28, 737 . 
Hegsted, D. M. (1963). Fedn Proc. Fedn Am. Socs exp. Biol. 22, 1424.

Hoffenberg, R. (1972). Proc. Nutr. Soc. 31, 265.

Hussein, M. A., Young, V. R., Murray, E. \& Scrimshaw, N. S. (1971). F. Nutr. ror, 6r.

Inoue, G., Fujita, Y. \& Niiyama, Y. (1973). F. Nutr. 103, 1673 .

Irwin, M. I. \& Hegsted, D. M. (1971). f. Nutr. 101, 539.

James, W. P. T. (1972). Proc. Nutr. Soc. 31, 225.

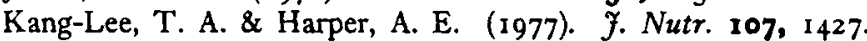

Kang-Lee, T. A. \& Harper, A. E. (1978). F. Nutr. 108, 163.

Kishi, Y., Miyatani, S. \& Inoue, G. (1978). F. Nutr. 108, 658.

Lemon, P. W. R. \& Mullin, J. P. (1980). F. appl. Physiol. 48, 624.

Long, C. L., Kenney, J. M. \& Geiger, J. W. (1976). Metabolism 25, 193.

Lund, P. (1981). In Nitrogen Metabolism in Man, [J. C. Waterlow and J. M. L. Stephen, editors]. London: Applied Sciences Publishers.

Matthews, D. E., Motil, K. J., Rohrbaugh, D. K., Burke, J. F., Young, V. R. \& Bier, D. M. (1980). Am. F. Physiol. 238, E473.

Millward, D. J. (1979). Proc. Nutr. Soc. $3^{8}, 77$.

Millward, D. J. \& Garlick, P. J. (1972). Proc. Nutr. Soc. 31, 257.

Millward, D. J., Garlick, P. J. \& Reeds, P. J. (1976). Proc. Nutr. Soc. 35, 339.

Motil, K. J., Bier, D. M., Matthews, D. E., Burke, J. F. \& Young, V. R. (1981). Metabolism (In the Press).

Motil, K. J., Matthews, D. E., Bier, D. M., Burke, J. F., Munro, H. N. \& Young, V. R. (1981). $A m$. 7. Physiol. 240, E712.

Munro, H. N. (1964). In Mammalian Protein Metabolism, vol. 2, p. 281 [H. N. Munro and J. B. Allison, editors]. New York: Academic Press.

Munro, H. N. (1969). Proc. Nutr. Soc. 28, 214.

Pion, R. (1973). In Proteins in Human Nutrition, p. 329 [J. W. G. Porter and B. A. Rolls, editors]. New York: Academic Press.

Reeds, P. J. \& Lobley, G. E. (1980). Proc. Nutr. Soc. 39, 43.

Robert, J.-J. (I $98 \mathrm{I}$ ). MIT PhD Thesis, Cambridge, Massachusetts.

Sherwin, R. S., Hendler, R. G. \& Felig, P. (1975). 于. clin. Invest. 22, 1382.

Simon, O., Adam, K. \& Bergner, H. (1978). Arch. Tierernaehrung 28, 609.

Simon, O., Munchmeyer, R., Bergner, H., Zebrowska, T. \& Buraczeska, L. (1978). Br. J. Nutr. 40, 243 .

Smith, R. H. (1980). Proc. Nutr. Soc. 39, 71.

Tanaka, H. \& Ogura, M. (1980). Agric. Biol. Chem. 44, 2343.

Tanaka, H., Yamaguchi, M. \& Kamateka, M. (1975). Agric. Biol. Chem. 39, 507.

Waterlow, J. C., Garlick, P. J. \& Millward, D. J. (1978). Protein Turnover in Mammalian Tissues and in the Whole Body. Amsterdam: North-Holland Pub. Co.

Waterlow, J. C. \& Stephen, J. M. L. (1969). Proc. Nutr. Soc. 28, 234.

Waterlow, J. C. \& Stephen, J. M. L. (1981). Nitrogen Metabolism in Man. London: Applied Sciences Publishers.

Williamson, D. H., Garrell, R., Kerr, A. \& Smith, R. (1977). Clin. Sci. Mol. Med. 52, 527. Wolfe, B. M., Culebras, J. M., Sim, A. J., Ball, M. R. \& Moore, F. D. (1977). Ann. Surg. 186, ${ }_{1} 18$.

Wolfe, R. R., Durkot, M. J., Allsop, J. R. \& Burke, J. F. (1979). Metabolism 28, 103 I.

Young, V. R., Hussein, M. A., Murray, E. \& Scrimshaw, N. S. (1969). Am. J. clin. Nutr. 22, ${ }_{563}$.

Young, V. R., Meguid, M., Meredith, C., Matthews, D. \& Bier, D. M. (1981). In Nitrogen Metabolism in Man [J. C. Waterlow and J. M. L. Stephen, editors]. London: Applied Sciences Publishers.

Young, V. R. \& Scrimshaw, N. S. (1978). In Protein Resources and Technology, p. 136 [M. Milner, N. S. Scrimshaw and D. I. C. Wang, editors]. Westport, Connecticut: AVI Press.

Young, V. R., Scrimshaw, N. S. \& Bier, D. M. (198I). F. Agric. Fd Chem. 29, 440. 